\title{
Using Soil Apparent Electrical Conductivity to Optimize Sampling of Soil Penetration Resistance and to Improve the Estimations of Spatial Patterns of Soil Compaction
}

\author{
Glécio Machado Siqueira, ${ }^{1}$ Jorge Dafonte Dafonte, ${ }^{2}$ Javier Bueno Lema, ${ }^{2}$ \\ Montserrat Valcárcel Armesto, ${ }^{2}$ and Ênio Farias França e Silva ${ }^{3}$ \\ ${ }^{1}$ Centro de Ciências Agrárias e Ambientais, Universidade Federal do Maranhão, BR-222, KM 04, s/n, \\ Boa Vista, 65500-000 Chapadinha, MA, Brazil \\ ${ }^{2}$ Escuela Politécnica Superior, Universidad de Santiago de Compostela (USC), Campus Universitario, 27002 Lugo, Spain \\ ${ }^{3}$ Departamento de Engenharia Agrícola, Universidade Federal Rural de Pernambuco (UFPRE), \\ Rua D. Manuel de Medeiros, s/n, 52171-900 Recife, PE, Brazil
}

Correspondence should be addressed to Glécio Machado Siqueira; gleciosiqueira@hotmail.com

Received 8 July 2014; Revised 26 September 2014; Accepted 7 October 2014; Published 31 December 2014

Academic Editor: Antonio Paz González

Copyright (C) 2014 Glécio Machado Siqueira et al. This is an open access article distributed under the Creative Commons Attribution License, which permits unrestricted use, distribution, and reproduction in any medium, provided the original work is properly cited.

\begin{abstract}
This study presents a combined application of an EM38DD for assessing soil apparent electrical conductivity $\left(\mathrm{EC}_{\mathrm{a}}\right)$ and a dualsensor vertical penetrometer Veris-3000 for measuring soil electrical conductivity $\left(\mathrm{EC}_{\mathrm{veris}}\right)$ and soil resistance to penetration (PR). The measurements were made at a 6 ha field cropped with forage maize under no-tillage after sowing and located in Northwestern Spain. The objective was to use data from $\mathrm{EC}_{\mathrm{a}}$ for improving the estimation of soil PR. First, data of $\mathrm{EC}_{\mathrm{a}}$ were used to determine the optimized sampling scheme of the soil PR in 40 points. Then, correlation analysis showed a significant negative relationship between soil PR and $\mathrm{EC}_{\mathrm{a}}$, ranging from -0.36 to -0.70 for the studied soil layers. The spatial dependence of soil PR was best described by spherical models in most soil layers. However, below $0.50 \mathrm{~m}$ the spatial pattern of soil PR showed pure nugget effect, which could be due to the limited number of PR data used in these layers as the values of this parameter often were above the range measured by our equipment $(5.5 \mathrm{MPa})$. The use of $\mathrm{EC}_{\mathrm{a}}$ as secondary variable slightly improved the estimation of $\mathrm{PR}$ by universal cokriging, when compared with kriging.
\end{abstract}

\section{Introduction}

Soil physical properties play an important role on crop growth, if not the most important [1]. On the other hand, soil cultivation under different land uses may cause changes in soil spatial variability, depending on tillage intensity [2].

The use of farm machinery in agricultural production systems disturbs the soil structure and often may generate soil compacted layers that affect soil aeration and infiltration capacity. Different soil management systems produce different levels of soil compaction, depending on water content, type of soil, and agricultural machinery operations.

Soil penetration resistance has been found to be well correlated with root growth, and these two variables are inversely proportional. When soil water content decreases, soil mechanical resistance increases, because of the diminution of cohesion within the solid fraction of soil [3-5]. Several authors have shown that root growth can be restricted or even impeded when PR values vary between 1.0 and $3.5 \mathrm{MPa}[6,7]$; however others quoted threshold between 2.0 and $4.0 \mathrm{MPa}$ [8] for limitations to root grow.

Hill and Meza-Montalvo [9] concluded that agricultural machinery traffic during the crop growth cycle may increase the values of soil density and soil resistance to penetration to $50 \%$. For this reason, the quantification of soil PR changes caused by soil management is an important parameter for maintaining desirable levels of production and environmental sustainability. 
Most farmers consider the soil as uniform for its management, but soil properties are variable in space and time. As a result of these variations, the use of the average value of a soil property could lead to wrong management decisions. This notwithstanding, conventional agriculture has been based on soil sampling with few samples [10].

The electrical conductivity (EC) is the property that has a material to transmit or conduct electrical current [11-14]. The apparent soil electrical conductivity $\left(\mathrm{EC}_{\mathrm{a}}\right)$ is a measure of the bulk electrical conductivity of the soil and is influenced by various factors such as soil porosity, concentration of dissolved electrolytes, texture, quantity and composition of colloids, organic matter, and water content in the soil [11]. Recent research found that apparent soil electrical conductivity measurements using electromagnetic sensors can be used to make rapid measurements of soil water content, soil clay content, cation exchange capacity and levels of exchangeable calcium and magnesium, depth of horizons with a "pan" caused by compaction, organic matter content, and salt content in soil solution [14]. In this way, measurements of apparent soil electrical conductivity $\left(\mathrm{EC}_{\mathrm{a}}\right)$ can be used to define specific management zones.

Rhoades et al. [11] and Nadler [12] claim that soils with high water content have a higher value of $\mathrm{EC}_{\mathrm{a}}$, which makes the interpretation of $\mathrm{EC}_{\mathrm{a}}$ data difficult. This is because the water content varies with depth, even if the soil is uniform, which may cause strong $\mathrm{EC}_{\mathrm{a}}$ variations as a function of depth. Moreover, temperature also affects the soil $\mathrm{EC}_{\mathrm{a}}[11$, 15]. This is because increased soil temperature has effect on water viscosity and therefore affects the mobility of dissolved electrolytes into the soil solution [16]. Summarizing, it is widely accepted that the main factors that influence $\mathrm{EC}_{\mathrm{a}}$ are texture, soil water content, and salinity [14, 17-19]; there is good correlation between these soil properties and $\mathrm{EC}_{\mathrm{a}}[20]$.

The aim of this study was to use apparent soil electrical conductivity data $\left(\mathrm{EC}_{\mathrm{a}}\right)$, measured by EM38, first to generate optimal soil sampling designs and then to improve the spatial estimation of soil resistance to penetration (PR) on the studied field.

\section{Material and Methods}

The studied field is 6 ha in surface, and it is located at Castro Riberas de Lea, Lugo, Northwestern Spain. The geographical coordinates are $43^{\circ} 09^{\prime} 49^{\prime \prime} \mathrm{N}$ and $7^{\circ} 29^{\prime} 47^{\prime \prime} \mathrm{W}$, average elevation is $410 \mathrm{~m}$ and average slope is $2 \%$. The soil of the study area is classified according to FAO-ISRIC [21] as Gleyc Cambisol. At the sampling date, the field was cropped with maize for silage under no tillage; before maize, the field was devoted to permanent grassland for silage. A more thorough description of this area can be found in Siqueira et al. [22].

The apparent soil electrical conductivity $\left(\mathrm{EC}_{\mathrm{a}}\right)$ was measured with an induction electromagnetic device, namely, EM38-DD (Geonics Limited). The EM38-DD is constructed by mechanically and electrically integrating two standard EM38 ground conductivity meters. The bottom instrument's transmitter-receiver dipoles are oriented parallel to the earth in horizontal dipole $\left(\mathrm{EC}_{\mathrm{a}}-\mathrm{H}\right)$, while for the top instrument,

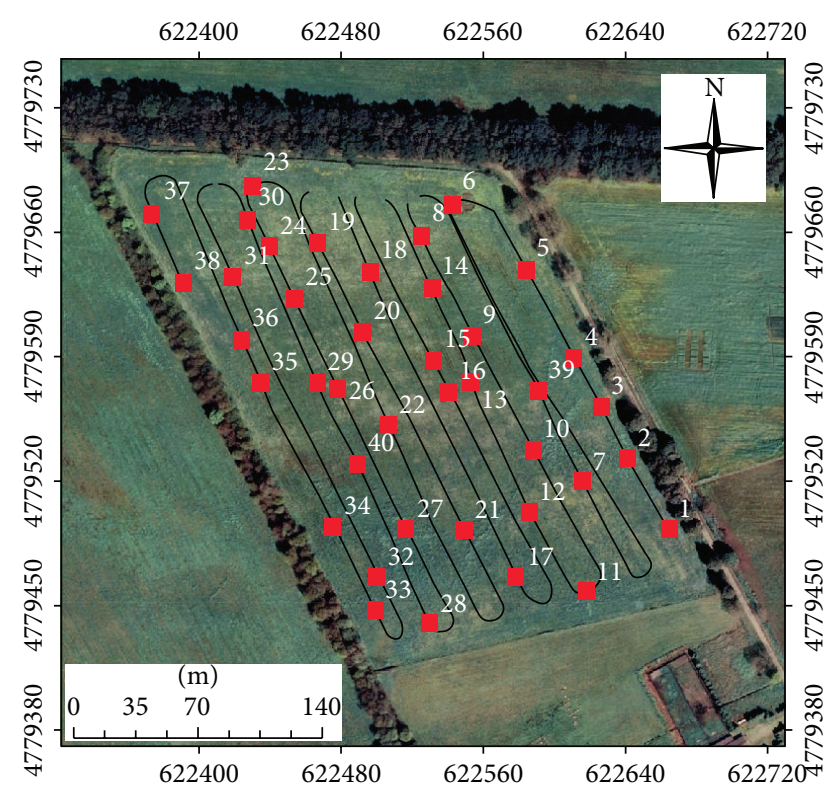

FIGURE 1: Continuous record of soil apparent electrical conductivity $\left(\mathrm{EC}_{\mathrm{a}}\right.$ ) obtained by electromagnetic induction (line) and the optimized sampling scheme consisting 40 points (circles).

which controls the digital output of the whole instrument, the dipoles are oriented perpendicular to the earth surface in vertical dipole $\left(\mathrm{EC}_{\mathrm{a}}-\mathrm{V}\right)$. In the $\mathrm{EC}_{\mathrm{a}}-\mathrm{V}$ mode, the primary magnetic field can effectively penetrate to a depth of $1.5 \mathrm{~m}$, while the $\mathrm{EC}_{\mathrm{a}}-\mathrm{H}$ mode is effective for shallower investigation $(0.75 \mathrm{~m})$ [12]. The data were collected on 23/6/2008 in 1859 points (Figure 1), using EM38DD a field computer and a GPS RTK to georeference $\mathrm{EC}_{\mathrm{a}}$ data.

The $\mathrm{EC}_{\mathrm{a}}$ data, together with the software ESAP-RSSD 2.35 [23], were used to identify the 40 optimal locations to perform measurements with the VERIS P3000 equipment (Figure 1). The penetrometer used in this research was the Profiler 3000, manufactured by Veris Technologies Inc. It was a self-contained, trailer mounted device, designed to be pulled through the field by a vehicle [24]. An onboard power unit and hydraulic cylinder were used to insert the penetrometer to a maximum depth of approximately $90 \mathrm{~cm}$. Maximum insertion force was limited to approximately $5.5 \mathrm{MPa}$ with the sensing tip, to prevent overload of the mechanical components and sensing system. A second hydraulic cylinder pivoted the penetrometer mast through a transverse arc, allowing approximately $90 \mathrm{~cm}$ of side-to-side displacement for acquiring data across in row and between row locations. Data collection was triggered every $2 \mathrm{~cm}$. Soil electrical conductivity $\left(\mathrm{EC}_{\mathrm{veris}}\right)$ was sensed immediately above the penetrometer tip. The penetrometer tip itself was electrically insulated from the penetrometer shaft with a thin dielectric ring. Electrical contact with the tip was by means of a small steel rod inside and insulated from the hollow shaft.

In this study the soil penetration resistance data was grouped into the following layers: $0.0-0.1 \mathrm{~m}\left(\mathrm{PR}_{0.0-0.1}\right), 0.1-$ $0.2 \mathrm{~m}\left(\mathrm{PR}_{0.1-0.2}\right), 0.2-0.3 \mathrm{~m}\left(\mathrm{PR}_{0.2-0.3}\right), 0.3-0.4 \mathrm{~m}\left(\mathrm{PR}_{0.3-0.4}\right)$, 0.4-0.5 m $\quad\left(\mathrm{PR}_{0.4-0.5}\right), \quad 0.5-0.6 \mathrm{~m} \quad\left(\mathrm{PR}_{0.5-0.6}\right), \quad 0.6-0.7 \mathrm{~m}$ 


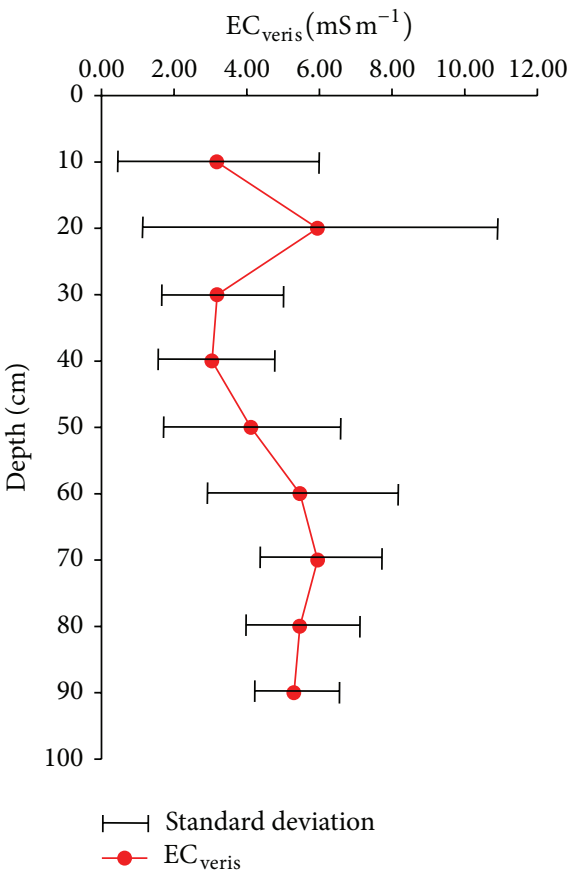

(a)

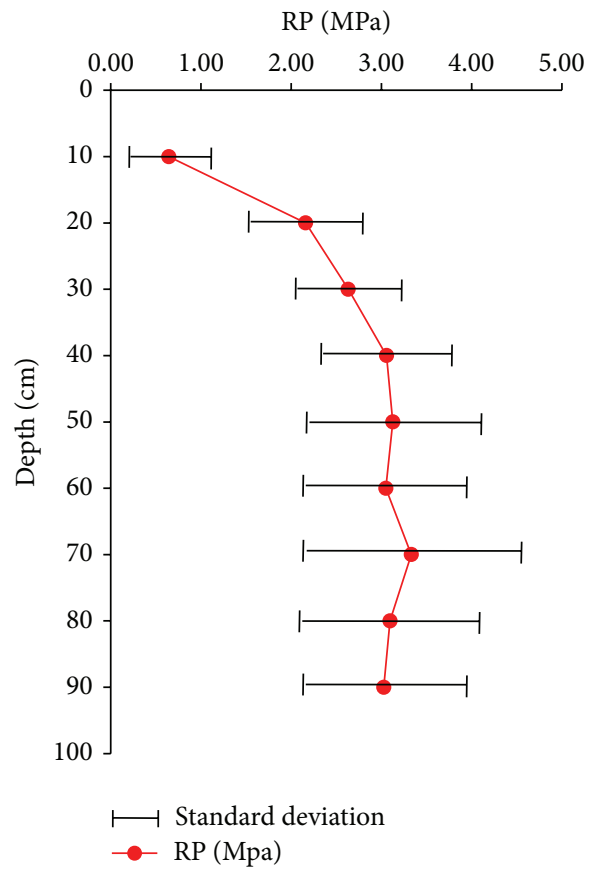

(b)

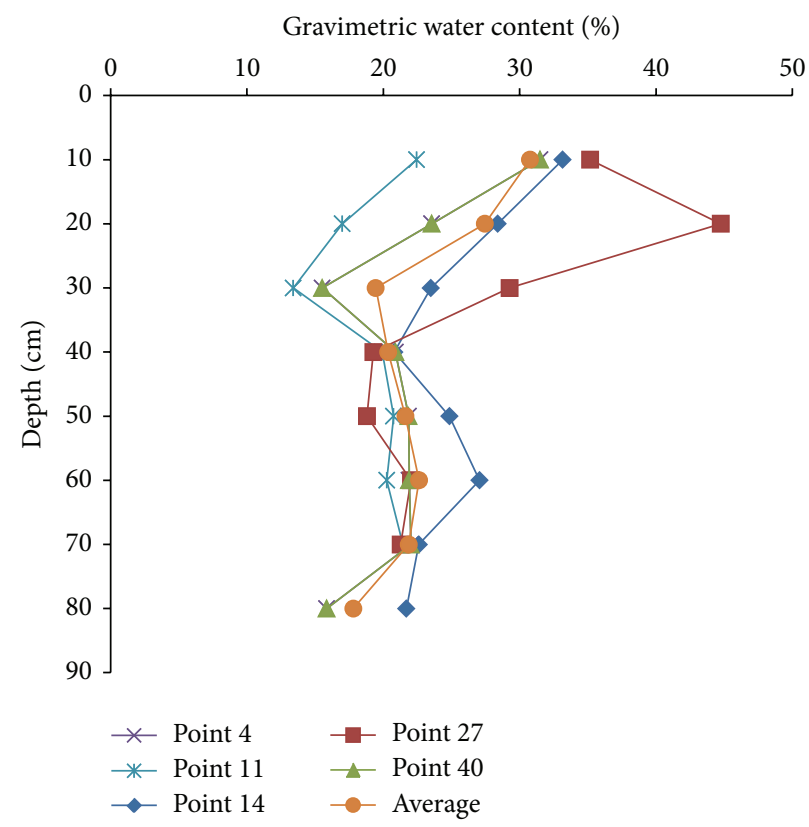

(c)

FIGURE 2: Mean values of $\mathrm{EC}_{\mathrm{veris}}$ measured continuously, penetration resistance (PR) measured at 40 points, and gravimetric water content at five selected points.

$\left(\mathrm{PR}_{0.6-0.7}\right)$, $0.7-0.8 \mathrm{~m} \quad\left(\mathrm{PR}_{0.7-0.8}\right)$, and $0.8-0.9 \mathrm{~m} \quad\left(\mathrm{PR}_{0.8-0.9}\right)$ (Figure 2). In each measurement location, the $\mathrm{PR}$ and $\mathrm{EC}_{\mathrm{veris}}$ profile was measured in six near points. Therefore, the PR and $\mathrm{EC}_{\mathrm{veris}}$ data showed for each location is the mean of the six profiles measured (Figures 2(a) and 2(b)).

Gravimetric soil water content was measured at these sampling points: $4,11,14,27$, and 40 (Figure 2(c)), in order to relate the $\mathrm{EC}_{\mathrm{a}}$ values with the soil water content. Pearson's coefficients of correlation and significance levels were calculated between the data using pairs with the package "hmisc" [25].

The geostatistical analysis included preliminary statistical analysis, Kolmogorov-Smirnov normality test, analysis of trend, variogram modeling, and estimating values for unsampled locations using the kriging interpolation technique. Initial analysis showed that some variables had 


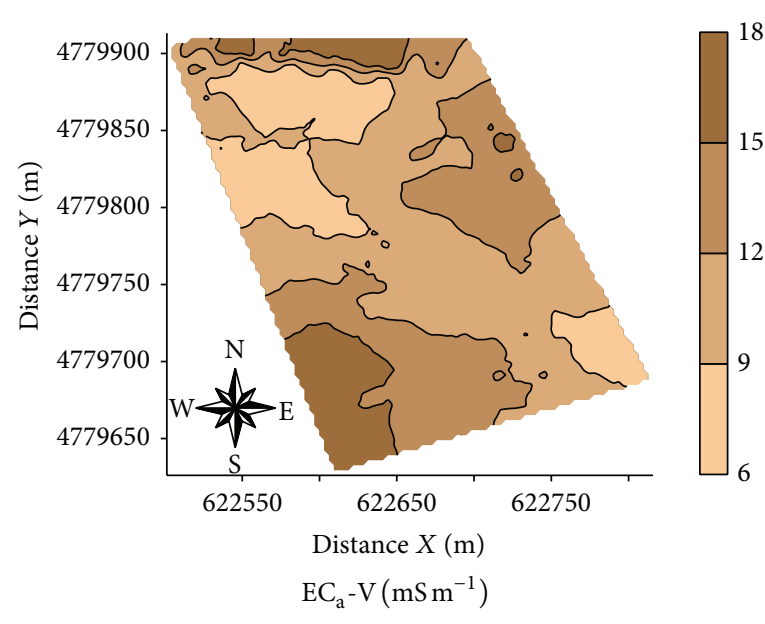

(a)

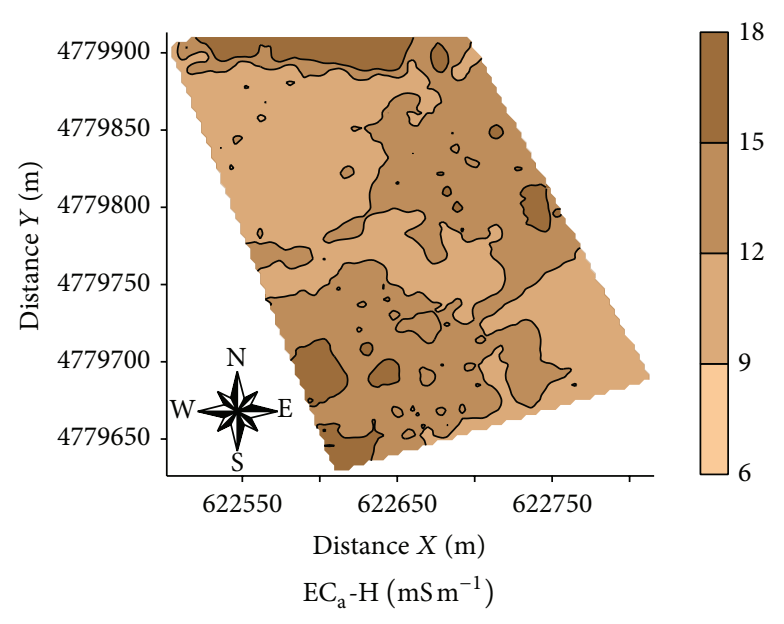

(b)

Figure 3: Maps of soil apparent electrical conductivity $\left(\mathrm{EC}_{\mathrm{a}}-\mathrm{V}\right.$ and $\left.\mathrm{EC}_{\mathrm{a}}-\mathrm{H}\right)$.

a trend; in this case the residual ordinary kriging was used.

Using geostatistics, there are two options to solve the problem created by the existence of a drift within the neighborhood search. On the one hand, it can be assumed that the drift is an equation with constant coefficients for the entire study area, which leads to residual kriging. On the other hand it can be assumed that coefficients of the drift equation vary by location of the study area, which results in universal kriging or kriging with trend model; this procedure simultaneously solves drift while kriging equations are solved. In this research the residual ordinary kriging was used (Table 3 ). The residual variograms were fitted to variogram models with cross validation using the package Gstat for R [26]; Surfer 7.0 software was used for the creation of the maps.

Some of the variables with a trend were interpolated by universal cokriging [27], instead of ordinary cokriging or cokriging with external drift. The software used to perform ordinary kriging, universal kriging, and universal cokriging was Gstat for R [26]. Using cokriging the covariance matrix must be positive definite [27-29].

\section{Results and Discussion}

Table 1 shows the statistical parameters for the apparent electrical conductivity $\left(\mathrm{EC}_{\mathrm{a}}\right)$ measured with EM38-DD and soil resistance to penetration $(\mathrm{PR})$ and electrical conductivity $\left(\mathrm{EC}_{\mathrm{veris}}\right)$ measured with penetrometer Veris P3000 (Table 4). All studied properties showed log-normal distribution with statistical Kolmogorov-Smirnov test with significance level of 0.01 .

Coefficient of variation of the studied properties had a moderate variability with values between 12 and $60 \%$, according to the classification of Warrick and Nielsen [1]. The following data sets had high $\mathrm{CV}$ values (>60\%): $\mathrm{EC}_{\mathrm{veris} 0-0.1}$; $\mathrm{EC}_{\mathrm{veris} 0.1-0.2} ; \mathrm{EC}_{\mathrm{veris}}$ average 0.0-0.4 $\mathrm{y} \mathrm{PR}_{0-0.1}$. The presence of high values of $\mathrm{CV}$ mainly for electrical conductivity $\left(\mathrm{EC}_{\mathrm{veris}}\right)$ were expected since the number of measurements was much lower (maximum 140), compared to $\mathrm{EC}_{\mathrm{a}}-\mathrm{V}$ and $\mathrm{EC}_{\mathrm{a}}-\mathrm{H}$ data measured with the EM38-DD device (1859 measurements, Figure 3).

The small number of measurements obtained with Veris P3000 at the deepest soil layers (Table 1) was mainly because the equipment has a safety valve that prevents the measurement of soil PR above $5.5 \mathrm{MPa}$. The presence of a compacted layer or gravel in the soil profile was the main reason for because reducing the number of measurements at the deepest layers. Figure 2 shows the average values of the electrical conductivity $\left(\mathrm{EC}_{\mathrm{veris}}\right.$, Figure $\left.2(\mathrm{a})\right)$, penetration resistance $(\mathrm{PR}$, Figure $2(\mathrm{~b}))$, and gravimetric water content (\%, Figure 2(c)) in the field studied.

The average values of the electrical conductivity measured with Veris penetrometer $\left(\mathrm{EC}_{\mathrm{veris}}\right)$ showed an increase with increasing depth, which is in accordance with results presented by Johnson et al. [30] and Motavalli et al. [31]. Increasing values of water content and soil clay content in depth, contributed to increased values of $\mathrm{EC}_{\mathrm{veris}}[32,33]$. The mean values of soil resistance to penetration (PR) increased in depth, but there was a slight decrease in the values of PR in depth below $0.5 \mathrm{~m}$ depth, because of a gravel layer located at this depth.

Figure 2(a) shows that the standard deviation of $\mathrm{EC}_{\mathrm{veris}}$ data is higher in the surface layers, decreasing in the deeper layers, the opposite occurs with PR data because in depth the stone volume is larger causing PR values exceeding in many cases the equipment measurement limit of $5.5 \mathrm{MPa}$, as reflected in the smaller number of measurements in these layers of soil (Table 1).

Gravimetric soil moisture was measured at locations 4, $11,14,27$, and 40 (Figure 2(c)); the choice of these locations was made on the basis of the topography of the area; these locations are representative for spatial variability of water content. It is seen that in the surface layers the water content 
TABLE 1: Statistical parameters of the apparent electrical conductivity $\left(\mathrm{EC}_{\mathrm{a}}\right)$ measured with EM38, in vertical and horizontal modes, and electrical conductivity $\left(\mathrm{EC}_{\mathrm{veris}}\right.$ ) and soil resistance to penetration $(\mathrm{PR})$ measured with VERIS P3000 at successive layers.

\begin{tabular}{|c|c|c|c|c|c|c|c|c|c|c|}
\hline Variable & Units & $N$ & Min. & Max. & Mean & Variance & $\mathrm{CV}$ & Skewness & Kurtosis & $D$ \\
\hline $\mathrm{EC}_{\mathrm{a}}-\mathrm{V}$ & \multirow{13}{*}{$\mathrm{mS} \mathrm{m}^{-1}$} & 1859 & 4.13 & 20.13 & 11.21 & 6.12 & 22.07 & 0.485 & -0.243 & $0.071 \mathrm{Ln}$ \\
\hline $\mathrm{EC}_{\mathrm{a}}-\mathrm{H}$ & & 1859 & 6.63 & 20.00 & 12.12 & 3.22 & 14.81 & 0.839 & 1.285 & $0.092 \mathrm{Ln}$ \\
\hline $\mathrm{EC}_{\text {veris } 0.0-0.1}$ & & 140 & 1.07 & 12.27 & 3.17 & 7.64 & 87.00 & 2.523 & 6.259 & $0.317 \mathrm{Ln}$ \\
\hline $\mathrm{EC}_{\text {veris } 0.1-0.2}$ & & 134 & 1.58 & 17.84 & 5.94 & 23.48 & 81.47 & 1.360 & 0.798 & $0.317 \mathrm{Ln}$ \\
\hline $\mathrm{EC}_{\text {veris } 0.2-0.3}$ & & 131 & 1.36 & 8.14 & 3.18 & 2.77 & 52.34 & 1.562 & 2.643 & $0.317 \mathrm{Ln}$ \\
\hline $\mathrm{EC}_{\text {veris } 0.3-0.4}$ & & 102 & 1.13 & 7.79 & 3.04 & 2.48 & 51.88 & 1.279 & 1.966 & $0.317 \mathrm{Ln}$ \\
\hline $\mathrm{EC}_{\text {veris } 0.4-0.5}$ & & 84 & 0.62 & 9.30 & 4.11 & 6.02 & 59.65 & -0.179 & -1.739 & $0.330 \mathrm{Ln}$ \\
\hline $\mathrm{EC}_{\text {veris } 0.5-0.6}$ & & 72 & 0.80 & 9.41 & 5.46 & 6.76 & 47.57 & -3.680 & -10.143 & $0.361 \mathrm{Ln}$ \\
\hline $\mathrm{EC}_{\text {veris } 0.6-0.7}$ & & 63 & 2.79 & 8.05 & 5.95 & 2.83 & 28.29 & -36.860 & -197.233 & $0.404 \mathrm{Ln}$ \\
\hline $\mathrm{EC}_{\text {veris } 0.7-0.8}$ & & 32 & 2.13 & 7.31 & 5.45 & 2.49 & 28.92 & -49.662 & -418.618 & $0.432 \mathrm{Ln}$ \\
\hline $\mathrm{EC}_{\text {veris } 0.8-0.9}$ & & 27 & 3.17 & 6.81 & 5.29 & 1.27 & 21.34 & -265.192 & -7150.197 & $0.513 \mathrm{Ln}$ \\
\hline $\mathrm{EC}_{\text {veris } 0.0-0.4}$ & & 507 & 1.40 & 9.32 & 3.83 & 5.74 & 62.47 & -1.511 & -14.054 & $0.317 \mathrm{Ln}$ \\
\hline $\mathrm{EC}_{\text {veris } 0.4-0.9}$ & & 278 & 0.62 & 7.94 & 4.51 & 5.09 & 49.96 & -39.185 & -39.185 & $0.330 \mathrm{Ln}$ \\
\hline $\mathrm{PR}_{0.0-0.1}$ & \multirow{11}{*}{$\mathrm{MPa}$} & 140 & 0.30 & 2.47 & 0.64 & 0.18 & 67.30 & 1.169 & 1.858 & $0.317 \mathrm{Ln}$ \\
\hline $\mathrm{PR}_{0.1-0.2}$ & & 134 & 1.10 & 3.28 & 2.16 & 0.40 & 29.41 & -26.517 & -121.478 & $0.317 \mathrm{Ln}$ \\
\hline $\mathrm{PR}_{0.2-0.3}$ & & 131 & 1.49 & 3.53 & 2.63 & 0.32 & 21.78 & -0.423 & -0.677 & $0.317 \mathrm{Ln}$ \\
\hline $\mathrm{PR}_{0.3-0.4}$ & & 102 & 1.68 & 4.85 & 3.05 & 0.53 & 23.89 & 0.265 & 0.025 & $0.317 \mathrm{Ln}$ \\
\hline $\mathrm{PR}_{0.4-0.5}$ & & 84 & 1.74 & 5.54 & 3.12 & 0.94 & 31.17 & -0.211 & 4.172 & $0.330 \mathrm{Ln}$ \\
\hline $\mathrm{PR}_{0.5-0.6}$ & & 72 & 1.92 & 5.32 & 3.04 & 0.86 & 30.43 & -19.154 & -60.403 & $0.381 \mathrm{Ln}$ \\
\hline $\mathrm{PR}_{0.6-0.7}$ & & 63 & 1.60 & 5.59 & 3.33 & 1.46 & 36.31 & -16.549 & -88.761 & $0.404 \mathrm{Ln}$ \\
\hline $\mathrm{PR}_{0.7-0.8}$ & & 32 & 1.54 & 4.85 & 3.09 & 0.99 & 36.26 & -34.572 & -285.556 & $0.432 \mathrm{Ln}$ \\
\hline $\mathrm{PR}_{0.8-0.9}$ & & 27 & 1.62 & 4.43 & 3.02 & 0.87 & 30.87 & -47.972 & -495.883 & $0.449 \mathrm{Ln}$ \\
\hline $\mathrm{PR}_{\text {average } 0.0-0.4}$ & & 507 & 1.18 & 3.06 & 2.12 & 0.26 & 24.05 & -48.771 & -233.173 & $0.317 \mathrm{Ln}$ \\
\hline $\mathrm{PR}_{\text {average 0.4-0.9 }}$ & & 278 & 1.95 & 5.54 & 3.40 & 0.98 & 29.21 & -33.401 & -207.070 & $0.330 \mathrm{Ln}$ \\
\hline
\end{tabular}

$N$ : number of measures (maximum six measurements in each location for EC $_{\text {veris }}$ and PR); Min.: minimum value; Max.: maximum value; CV: coefficient of variation (\%); $D$ : normality of the data for test of Kolmogorov-Smirnov $(P<0.01$, n: normality and Ln: lognormality).

varies more than in the deeper layers. The topsoil has higher water content than in the deeper layers in the sampling date.

In Figure 2(a) it can be seen that the graph of $\mathrm{EC}_{\mathrm{a}}$ is very similar to the soil water content graph (\%, Figure $2(\mathrm{c})$ ). Thus, $\mathrm{EC}_{\mathrm{veris}}$ dataset obtained by the penetrometer Veris is an indirect way to obtain information about the soil water status, facilitating the interpretation of PR data, because the direct measurement of the volumetric water content of the soil is hard and slow, particularly in this type of soil with a high $\left(>370,00 \mathrm{~g} \mathrm{~kg}^{-1}\right)$ amount of stones [34]. Motavalli et al. [31] studied the use of equipment Veris P3000 to detect the effects of compaction, and they found that the values of $\mathrm{EC}_{\mathrm{a}}$ were correlated with soil compaction and clay content in the soil profile, thereby enabling to relate $\mathrm{EC}_{\mathrm{a}}$ with $\mathrm{PR}$.

Figure 4 shows the relationship between soil water content and $\mathrm{EC}_{\mathrm{veris}}$ for the locations where soil water content was measured. It is apparent that there is no good correlation between $\mathrm{EC}_{\text {veris }}$ and gravimetric soil water for the selected points; to assess dependence between these two variables, more soil water content measurements would be needed.

Sudduth et al. [33] comparing the penetrometer Veris P3000 with ASAE Standard penetrometer found no significant differences between the values of soil resistance to penetration (PR) for different penetrometers studied. Canarache [6] showed that in addition to soil moisture, also PR is related

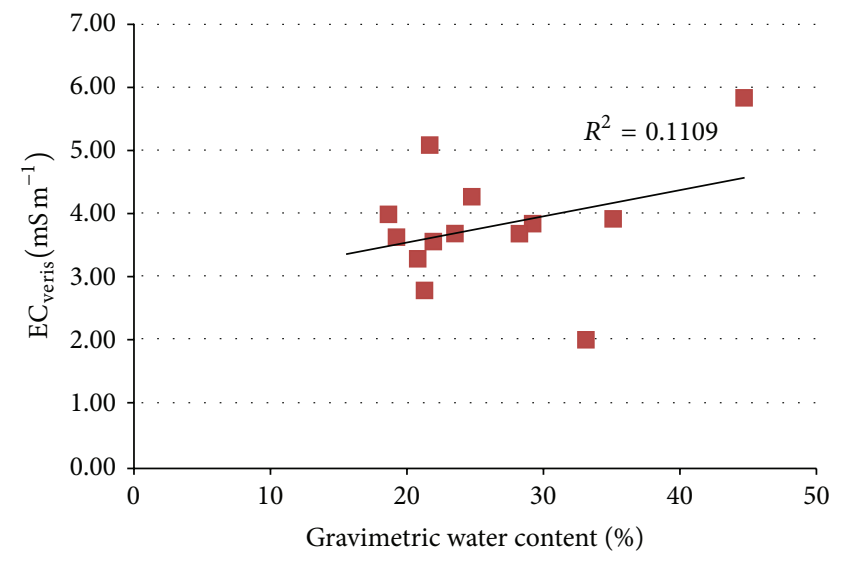

FIgURE 4: Correlation between $\mathrm{EC}_{\text {veris }}$ and gravimetric soil water content.

to other soil properties such as bulk density fine sand, sand, and clay contents. However, several authors claim that PR values are mainly related to moisture and soil bulk density [35-37]. In our case study, as soil sampling became difficult due to increasing gravel content in depth, PR measurements were essential to assess the physical status of the soil. 
Summarizing, we showed that the joint use of $\mathrm{EC}_{\mathrm{veris}}$ and PR data can detect changes in soil density and water content due to compaction, in addition to natural variations in soil texture.

Several authors provided different soil PR threshold values, regarding limitations for crop production. For example, Taylor and Gardner [37] reported that PR values greater than $2 \mathrm{MPa}$ inhibit vegetative growth. Taylor and Burnett [38] studied the development of different crops (Gossypium hirsutum, Sesamum indicum, Cyamopsis tetragonolobus, Sesbania exaltata, Phaseolus aureus, Vigna sinensis var. Chinese Red, and Sorghum vulgare var. Sumac sorghum) with different tillage systems, these authors describe that values from $2.8 \mathrm{MPa}$ began to restrict the root growth. Ehlers et al. [39] studied root growth of oats (Avena sativa L.) in the $0-0.25 \mathrm{~m}$ layer and found that root growth ceased when $\mathrm{PR}$ reached values between 3.6 and 4.9 MPa. Letey [40] and Bueno et al. [41] noted that soil PR values to higher than 2.0 $\mathrm{MPa}$ are restrictive to root growth.

Bennie [42] stated that more important than soil PR is the rate at which changes occur in soil bulk density until critical density values for vegetative growth are achieved. Bueno et al. [41] studied the PR in the $0-0.25 \mathrm{~m}$ layer at a field neighboring to our experimental field under no-till and conventional tillage and found PR values between 0.0 and 3.0 MPa depending on soil water content. In general, the mean value of $\mathrm{PR}$ for $0-0.4 \mathrm{~m}$ layer $\left(\mathrm{PR}_{\text {average } 0.0-0.4}\right)$ in this study was about $2.12 \mathrm{MPa}$. This value was close to the $2 \mathrm{MPa}$ threshold, commonly cited as restrictive for crop growth. $\mathrm{PR}_{\text {average } 0.4-0.9}$ was $3.40 \mathrm{MPa}$, exceeding the value of $2 \mathrm{MPa}$. However, the average soil water content of this layer is more stable over the study field, as shown in Figure 3, whereas the soil moisture content at $0.0-0.4 \mathrm{~m}$ layer varied considerably over this field.

Bueno [43] and Amiama [44], studying the PR at 0.0$0.4 \mathrm{~m}$ depth in a field near to the area studied here in several years, found similar values of $\mathrm{PR}$, the higher values of $\mathrm{PR}$ were found in the depth layers. Amiama [44] found a moderate correlation between PR and soil water content values.

Table 2 shows the correlation matrix between the measured variables. There is a significant correlation between $\mathrm{EC}_{\mathrm{a}}$ data EM38-DD and $\mathrm{EC}_{\mathrm{veris}}$, but the correlation $\mathrm{s}$ was not significant below $0.6 \mathrm{~m}$ depth. Probably, the lack of correlation at the deepest soil layers is related to the small number of sampling points in these layers obtained with the penetrometer Veris; in turn this is the result of the high content of gravel with depth.

Pearson's correlations between $\mathrm{EC}_{\mathrm{a}}$ and $\mathrm{PR}$ show highly significant negative relationships. This is because $\mathrm{EC}_{\mathrm{a}}$ is very dependent on the soil water content [11, 12, 14]; Hoefer et al. [45] found good correlations between PR and $\mathrm{EC}_{\mathrm{a}}$ measured with EM38, and they concluded that EM38 survey can be used to detect subplots with an extreme compaction or noncompaction state. According to Ehlers et al. [39] PR is much more influenced by soil water content than by soil bulk density. The electrical conductivity and PR data obtained with Veris P3000 showed negative significant correlation, which matches the negative correlations between $\mathrm{EC}_{\mathrm{a}}$ and PR. According to Drummond et al. [24] although there are

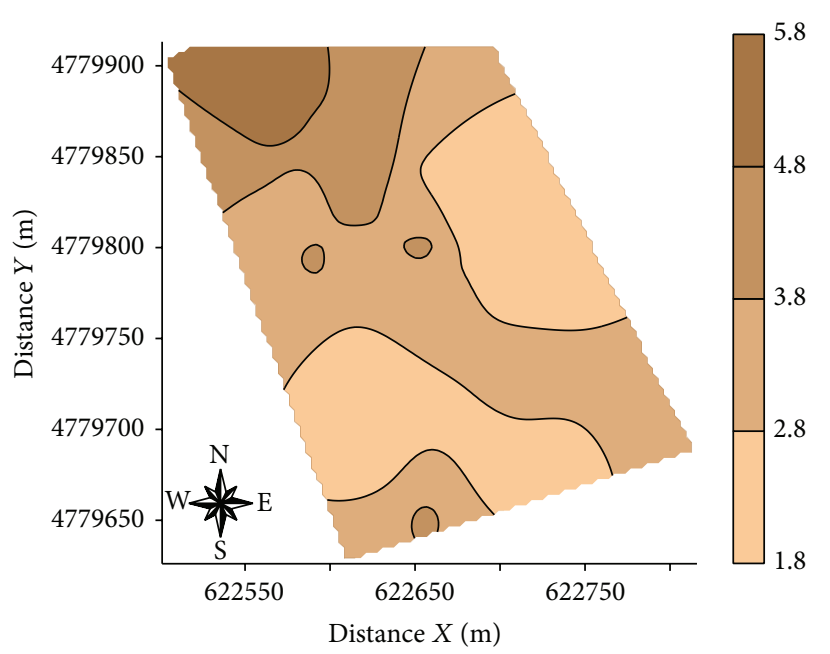

FIGURE 5: Map of $\mathrm{EC}_{\text {veris average } 0.4-0.9}\left(\mathrm{mS} \cdot \mathrm{m}^{-1}\right)$ obtained by universal cokriging.

various equipment available for measuring soil resistance to penetration and soil electrical conductivity, the joint measurement of $\mathrm{PR}$ and $\mathrm{EC}_{\mathrm{veris}}$ would allow to characterize the soil not only along the landscape but also in depth. This could contribute not only to the understanding of the spatial distribution of PR and $\mathrm{EC}_{\mathrm{a}}$, but also to assessing density, texture, and water content in the soil.

Table 5 shows the type of variogram models fitted to the experimental data and the parameters of these models. $\mathrm{EC}_{\mathrm{veris}} 0.0-0.1, \mathrm{EC}_{\mathrm{veris} \mathrm{0.1-0.2}}, \mathrm{EC}_{\mathrm{veris} \mathrm{0.2-0.3}}, \mathrm{EC}_{\mathrm{veris} \mathrm{0.3-0.4}}$, $\mathrm{EC}_{\text {veris } 0.4-0.5}, \quad \mathrm{EC}_{\text {veris } 0.5-0.6}, \quad \mathrm{EC}_{\text {veris } 0.5-0.6}, \mathrm{EC}_{\text {veris } 0.7-0.8}$, $\mathrm{EC}_{\text {veris 0.8-0.9 }}, \mathrm{EC}_{\text {veris average 0.0-0.4 }} \mathrm{PR}_{0.5-0.6}, \mathrm{PR}_{0.6-0.7}, \mathrm{PR}_{0.7-0.8}$, and $\mathrm{PR}_{0.8-0.9}$ showed pure nugget effect. This might indicate that the spacing used between samples was not adequate to detect the spatial variability but may also reflect the small number of points used in the analysis process. The values of the degree of spatial dependence showed that all variables studied had a high value of this parameter, following the accredited criteria of Cambardella et al. [46]. Spherical models were fitted to the experimental variograms of most studied variables $\left(\mathrm{EC}_{\mathrm{a}}-\mathrm{V}, \mathrm{EC}_{\mathrm{a}}-\mathrm{H}, \mathrm{EC}_{\mathrm{veris}}\right.$ average 0.4-0.9, $\mathrm{PR}_{0.0-0.1}, \mathrm{PR}_{0.1-0.2}, \mathrm{PR}_{0.2-0.3}, \mathrm{PR}_{0.3-0.4}, \mathrm{PR}_{0.4-0.5}, \mathrm{PR}_{\text {average } 0.0-0.4}$, and $\mathrm{PR}_{\text {average } 0.4-0.9}$ ). The lower range value (a) corresponds to $\log \mathrm{EC}_{\text {veris average } 0.4-0.9}(50 \mathrm{~m})$, whereas the highest value was found for Log $\mathrm{PR}_{\text {average 0-0.4 }}(130 \mathrm{~m})$. Jabro et al. [47] studied the spatial variability of the $\mathrm{EC}_{\mathrm{a}}\left(\mathrm{mS} \mathrm{m}^{-1}\right)$ and $\mathrm{PR}$ $(\mathrm{MPa})$ with the Veris penetrometer described values of range for both parameters of $161 \mathrm{~m}$; the values of range in this study were for Veris penetrometer approximately $50 \mathrm{~m}$ for $\mathrm{EC}_{\text {veris average 0.4-0.9 }}$ and $130 \mathrm{~m}$ and $70 \mathrm{~m}$ for the $\mathrm{PR}_{0.0-0.4}$ and $\mathrm{PR}_{\text {average } 0.4-0.9}$, respectively. Figures 5,6 , and 7, respectively, show the maps for $\mathrm{EC}_{\mathrm{a}}-\mathrm{V}, \mathrm{EC}_{\mathrm{a}}-\mathrm{H}, \mathrm{EC}_{\text {veris average } 0.4-0.9}$, and $\mathrm{PR}$ $\left(\mathrm{PR}_{0.0-0.1}, \mathrm{PR}_{0.1-0.2}, \mathrm{PR}_{0.2-0.3}, \mathrm{PR}_{0.3-0.4}, \mathrm{PR}_{0.4-0.5}, \mathrm{PR}_{\text {average } 0.0-0.4}\right.$, and $\mathrm{PR}_{\text {average } 0.4-0.9}$ ).

The map of the $\mathrm{EC}_{\mathrm{veris}}$ average 0.4-0.9 (Figure 6) has a similar spatial pattern to $\mathrm{EC}_{\mathrm{a}}-\mathrm{V}$ and $\mathrm{EC}_{\mathrm{a}}-\mathrm{H}$ (Figure 5), exhibiting varying $\mathrm{EC}$ in specific areas, in the eastern part of the area 


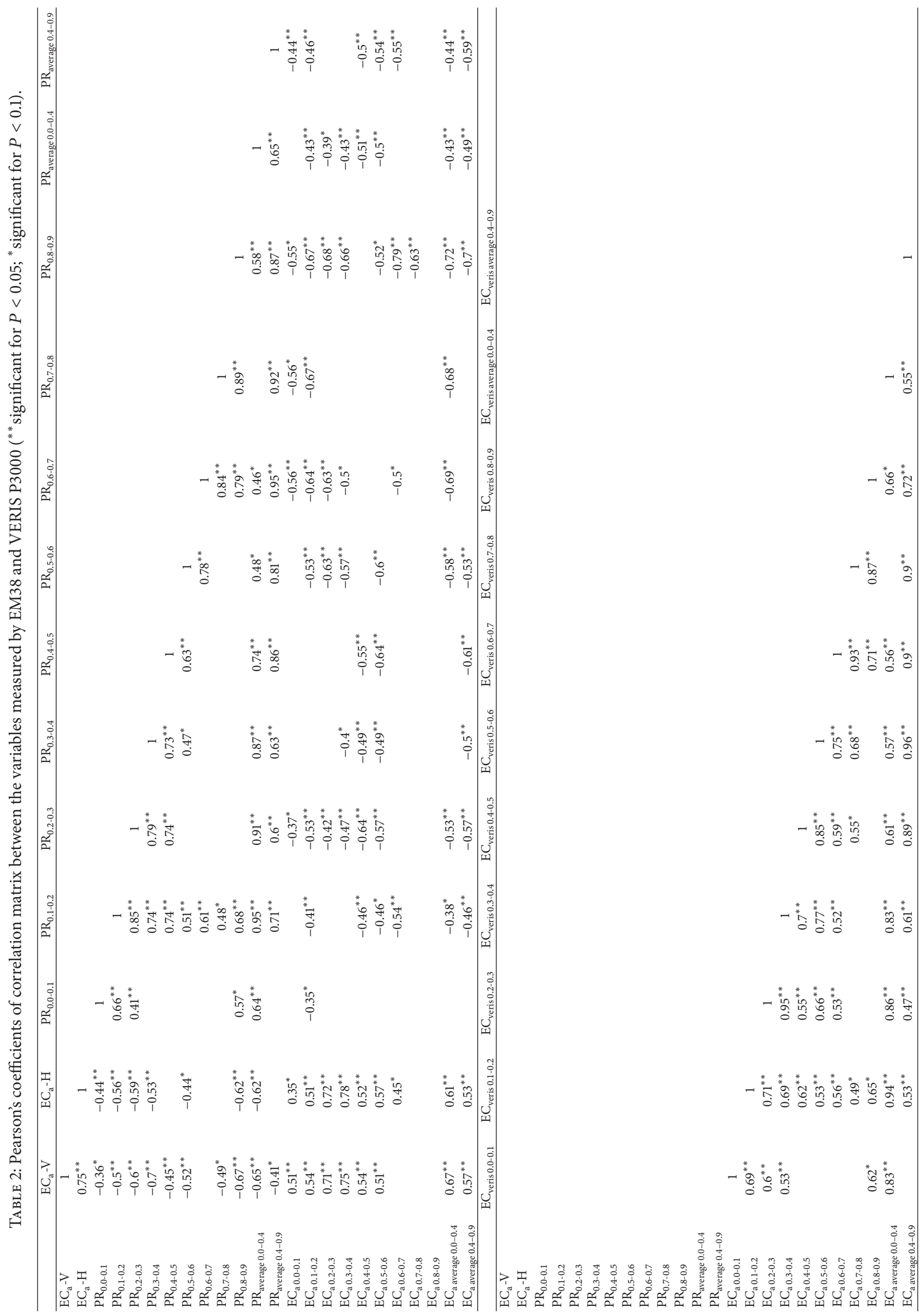




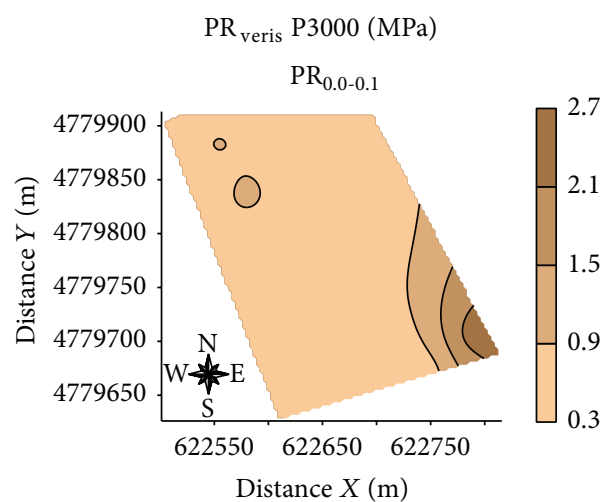

(a)

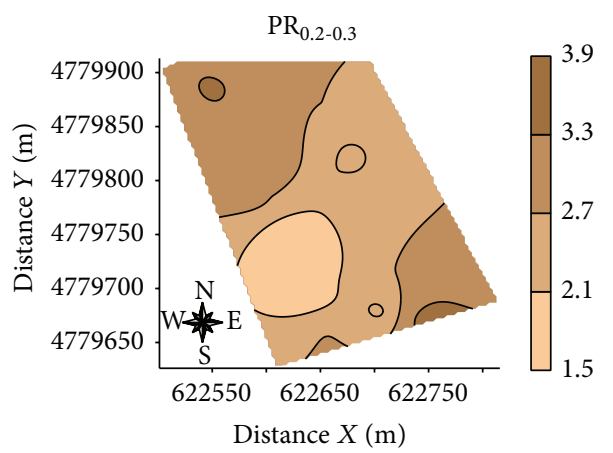

(c)

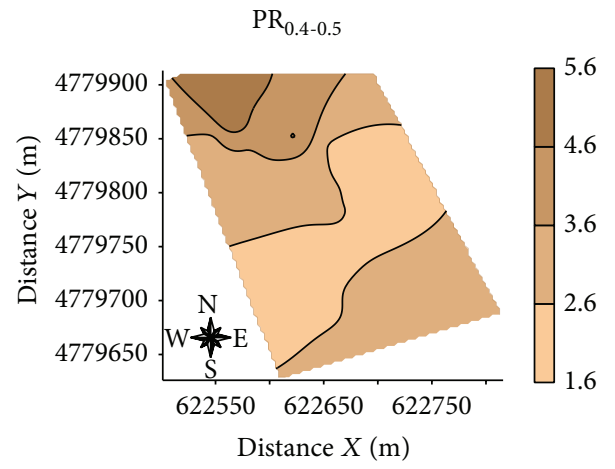

(e)

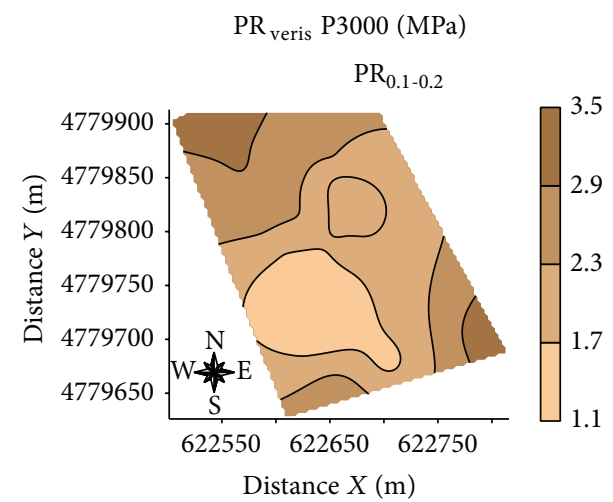

(b)

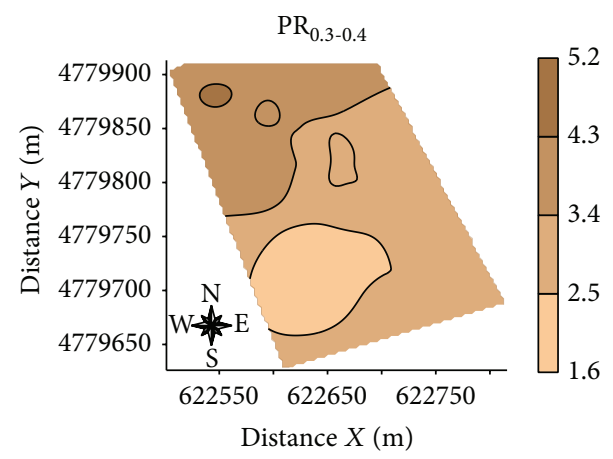

(d)

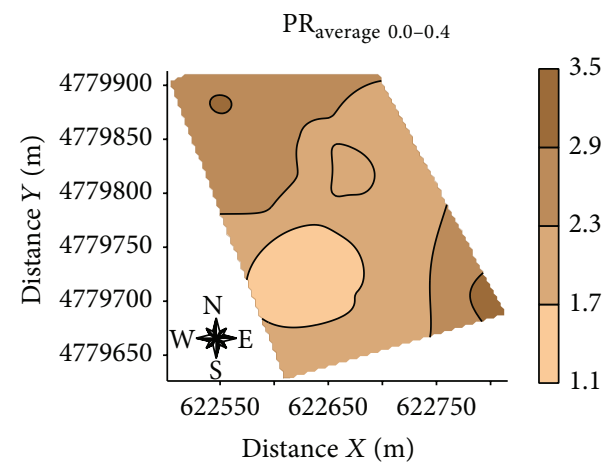

(f)

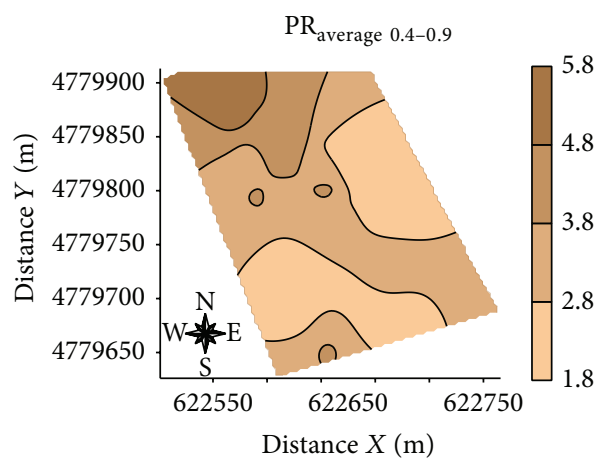

(g)

FIGURE 6: Maps of soil resistance to penetration measured with the penetrometer Veris $\left(\mathrm{PR}_{0.0-0.1}, \mathrm{PR}_{0.1-0.2}, \mathrm{PR}_{0.2-0.3}, \mathrm{PR}_{0.3-0.4}, \mathrm{PR}_{0.4-0.5}\right.$, $\mathrm{PR}_{0.0-0.4 \text { average }}$, and $\left.\mathrm{PR}_{\text {average } 0.4-0.9}\right)$ obtained by universal kriging. 
TABLE 3: Fitted models and variogram parameters for all the variables measured by EM38 and VERIS P3000.

\begin{tabular}{|c|c|c|c|c|c|}
\hline Variable & Geostatistical analysis & Model & $\mathrm{C}_{0}$ & $C_{1}$ & $a(\mathrm{~m})$ \\
\hline $\log \mathrm{EC}_{\mathrm{a}}-\mathrm{V}$ & Universal kriging & Spherical & 0.001 & 0.01 & 130.00 \\
\hline $\log \mathrm{EC}_{\mathrm{a}}-\mathrm{H}$ & Universal kriging & Spherical & 0.001 & 0.005 & 130.00 \\
\hline $\log \mathrm{EC}_{\mathrm{a} 0.0-0.1}$ & Universal kriging & \multicolumn{4}{|c|}{ Pure nugget effect } \\
\hline $\log \mathrm{EC}_{\mathrm{a} 0.1-0.2}$ & Universal kriging & \multicolumn{4}{|c|}{ Pure nugget effect } \\
\hline $\log \mathrm{EC}_{\mathrm{a} 0.2-0.3}$ & Universal kriging & \multicolumn{4}{|c|}{ Pure nugget effect } \\
\hline $\log \mathrm{EC}_{\mathrm{a} 0.3-0.4}$ & Universal kriging & \multicolumn{4}{|c|}{ Pure nugget effect } \\
\hline $\log \mathrm{EC}_{\mathrm{a} 0.4-0.5}$ & Universal kriging & \multicolumn{4}{|c|}{ Pure nugget effect } \\
\hline $\log \mathrm{EC}_{\mathrm{a} 0.5-0.6}$ & Universal kriging & \multicolumn{4}{|c|}{ Pure nugget effect } \\
\hline $\log \mathrm{EC}_{\mathrm{a} 0.6-0.7}$ & Universal kriging & \multicolumn{4}{|c|}{ Pure nugget effect } \\
\hline $\log \mathrm{EC}_{\mathrm{a} 0.7-0.8}$ & Universal kriging & \multicolumn{4}{|c|}{ Pure nugget effect } \\
\hline $\log \mathrm{EC}_{\mathrm{a} 0.8-0.9}$ & Universal kriging & \multicolumn{4}{|c|}{ Pure nugget effect } \\
\hline $\log \mathrm{EC}_{\mathrm{a} \text { average } 0.0-0.4}$ & Universal kriging & \multicolumn{4}{|c|}{ Pure nugget effect } \\
\hline $\log \mathrm{EC}_{\mathrm{a} \text { average } 0.4-0.9}$ & Universal kriging & Spherical & 0.01 & 0.10 & 50.00 \\
\hline $\log \mathrm{PR}_{0.0-0.1}$ & Universal kriging & Spherical & 0.00 & 0.045 & 90.00 \\
\hline $\log \mathrm{PR}_{0.1-0.2}$ & Universal kriging & Spherical & 0.00 & 0.014 & 125.00 \\
\hline $\log \mathrm{PR}_{0.2-0.3}$ & Universal kriging & Spherical & 0.00 & 0.011 & 120.00 \\
\hline $\log \mathrm{PR}_{0.3-0.4}$ & Universal kriging & Spherical & 0.00 & 0.011 & 90.00 \\
\hline $\log \mathrm{PR}_{0.4-0.5}$ & Universal kriging & Spherical & 0.00 & 0.017 & 100.00 \\
\hline $\log \mathrm{PR}_{0.5-0.6}$ & Universal kriging & \multicolumn{4}{|c|}{ Pure nugget effect } \\
\hline $\log \mathrm{PR}_{0.6-0.7}$ & Universal kriging & \multicolumn{4}{|c|}{ Pure nugget effect } \\
\hline $\log \mathrm{PR}_{0.7-0.8}$ & Universal kriging & \multicolumn{4}{|c|}{ Pure nugget effect } \\
\hline $\log \mathrm{PR}_{0.8-0.9}$ & Universal kriging & \multicolumn{4}{|c|}{ Pure nugget effect } \\
\hline $\log \mathrm{PR}_{\text {average } 0.0-0.4}$ & Universal kriging & Spherical & 0.00 & 0.015 & 130.00 \\
\hline $\log \mathrm{PR}_{\text {average 0.4-0.9 }}$ & Universal kriging & Spherical & 0.00 & 0.0095 & 70.00 \\
\hline
\end{tabular}

$C_{0}$ : pure nugget effect; $C_{1}$ : structural variance; $a$ : range.

TABLE 4: Fitted models and parameters of the cross-variograms between PR and $\mathrm{EC}_{\mathrm{a}}$.

\begin{tabular}{lcccc}
\hline Variable & Geostatistical Analysis & Model & $C_{0}$ & $C_{1}$ \\
\hline $\log \mathrm{PR}_{\text {average } 0.0-0.4} \times \log \mathrm{EC}_{\mathrm{a}}-\mathrm{V}$ & Universal cokriging & Spherical & 0.00 & 0.0095 \\
$\log \mathrm{PR}_{\text {average } 0.0-0.4} \times \log \mathrm{EC}_{\mathrm{a}}-\mathrm{H}$ & Universal cokriging & Spherical & 0.00 & 130.00 \\
$\log \mathrm{PR}_{\text {average } 0.4-0.9} \times \log \mathrm{EC}_{\mathrm{a}}-\mathrm{V}$ & Universal cokriging & Spherical & 0.00 & 0.0065 \\
$\log \mathrm{PR}_{\text {average } 0.4-0.9} \times \log \mathrm{EC}_{\mathrm{a}}-\mathrm{H}$ & Universal cokriging & Spherical & 0.00 & 0.0100 \\
\hline
\end{tabular}

$C_{0}$ : Pure nugget effect; $C_{1}$ : structural variance; $a$ : range.

TABLE 5: Correlation coefficient $(r)$ between measured and estimated data by kriging and cokriging for selected variables.

\begin{tabular}{|c|c|c|c|}
\hline \multicolumn{2}{|c|}{ Universal Kriging } & \multicolumn{2}{|l|}{ Universal Cokriging } \\
\hline \multirow{2}{*}{$\log \mathrm{PR}_{\text {average } 0.0-0.4}$} & \multirow{2}{*}{0.644} & $\log \mathrm{PR}_{\text {average } 0.0-0.4} \times \log \mathrm{EC}_{\mathrm{a}}-\mathrm{V}$ & 0.676 \\
\hline & & $\log \mathrm{PR}_{\text {average } 0.0-0.4} \times \log \mathrm{EC}_{\mathrm{a}}-\mathrm{H}$ & 0.696 \\
\hline \multirow{2}{*}{$\log \mathrm{PR}_{\text {average } 0.4-0.9}$} & \multirow{2}{*}{0.339} & $\log \mathrm{PR}_{\text {average 0.4-0.9 }} \times \log \mathrm{EC}_{\mathrm{a}}-\mathrm{V}$ & 0.392 \\
\hline & & $\log \mathrm{PR}_{\text {average 0.4-0.9 }} \times \log \mathrm{EC}_{\mathrm{a}}-\mathrm{H}$ & 0.415 \\
\hline
\end{tabular}

that exhibits low EC values in both maps. $\mathrm{EC}_{\mathrm{veris}}$ average $0.4-0.9$ map exhibits areas with higher $\mathrm{EC}_{\mathrm{a}}$ data, especially in the right center area, this difference in depth of the EC measured with the penetrometer Veris is probably related to the greater water content in depth or with areas where the clay content is increased [11, 12, 14, 19, 47]. We emphasize that the EM38$\mathrm{DD}$ gives a value of $\mathrm{EC}_{\mathrm{a}}$ it is a measure of the interactions of electromagnetic pulse with a specific volume of soil (water content, density, porosity, clay content, organic matter, etc.) [14] and the penetrometer Veris measures EC in a comparatively small soil volume, providing a better description of the characteristics of the soil in depth, according to what is described by Drummond et al. [24], Sudduth et al. [33], and Jabro et al. [47].

The matrix of linear correlation between the measured data with the EM38-DD equipment $\left(\mathrm{EC}_{\mathrm{a}}-\mathrm{V}\right.$ and $\left.\mathrm{EC}_{\mathrm{a}}-\mathrm{H}\right)$ with $\mathrm{EC}$ measured with the penetrometer Veris $\left(\mathrm{EC}_{\mathrm{a}} 0.0-0.1\right.$, $\mathrm{EC}_{\mathrm{a} 0.1-0.2}, \quad \mathrm{EC}_{\mathrm{a} 0.2-0.3}, \quad \mathrm{EC}_{\mathrm{a} 0.3-0.4}, \quad \mathrm{EC}_{\mathrm{a} 0.4-0.5}, \quad \mathrm{EC}_{\mathrm{a} 0.5-0.6}$, $\mathrm{EC}_{\mathrm{a} 0.6-0.7}, \quad \mathrm{EC}_{\mathrm{a} 0.7-0.8}, \quad \mathrm{EC}_{\mathrm{a} 0.8-0.9}, \quad \mathrm{EC}_{\mathrm{a} \text { average 0.0-0.4, }}$ and $\mathrm{EC}_{\mathrm{a} \text { average 0.4-0.9 }}$ ) (Table 2) confirms the relationship between measures of the $\mathrm{EC}_{\mathrm{a}}$.

The maps of spatial variability of soil penetration resistance (Figure 7) show that the highest values of PR are located mainly in the northwestern part of the area $\left(\mathrm{PR}_{0.1-0.2}, \mathrm{PR}_{0.2-0.3}\right.$, 


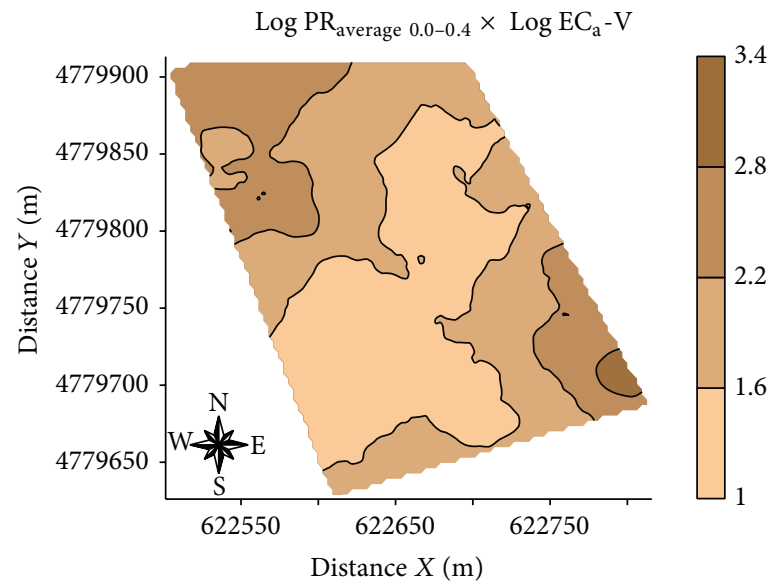

(a)

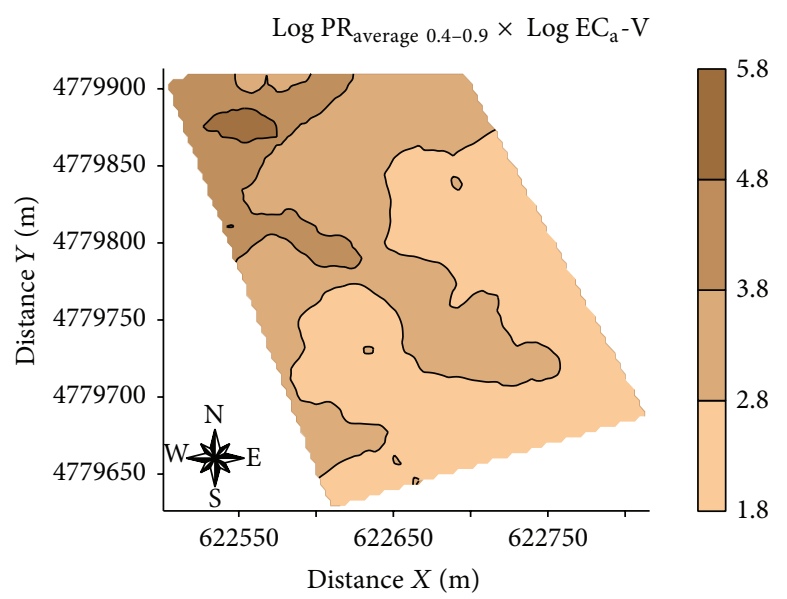

(c)

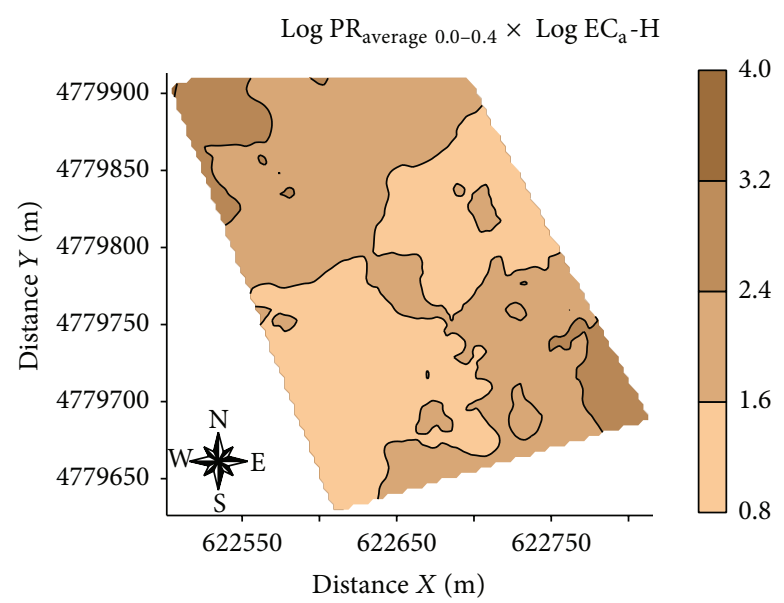

(b)

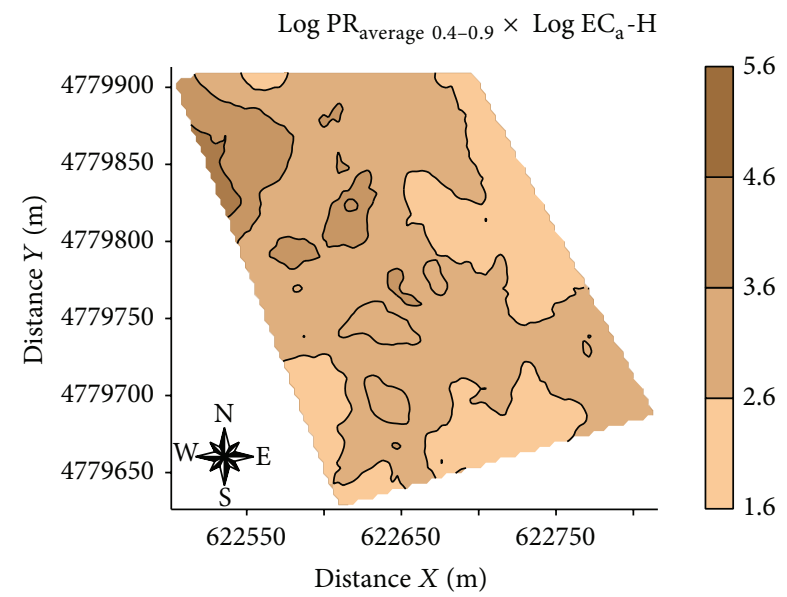

(d)

FIGURE 7: Maps of soil resistance to penetration at the layers $0.0-0.4 \mathrm{~m}\left(\mathrm{PR}_{\text {average } 0.0-0.4}\right)$ and $0.4-0.9 \mathrm{~m}\left(\mathrm{PR}_{\text {average } 0.4-0.9}\right)$ obtained by universal cokriging using $\mathrm{EC}_{\mathrm{a}}-\mathrm{V}$ and $\mathrm{EC}_{\mathrm{a}}-\mathrm{H}$ as secondary variables.

$\mathrm{PR}_{0.3-0.4}, \mathrm{PR}_{0.4-0.5}, \mathrm{PR}_{\text {average 0.0-0.4 }}$, and $\mathrm{PR}_{\text {average 0.4-0.9 }}$ ). Maps of $\mathrm{PR}$ show the opposite behavior to $\mathrm{EC}_{\mathrm{veris}}$ average 0.4-0.9 confirming the negative correlation (Figures 5 and 6), where areas with higher $\mathrm{EC}_{\mathrm{a}}$ showed lower values of $\mathrm{PR}$, corroborating the hypothesis that EC data measured with Veris penetrometer can be used as indicator of soil water content. According to Canarache [6] PR values can be classified according to the degree of constraint on the growth of roots $<1.1 \mathrm{MPa}$ very low without limitation for crops; low 1.12.5 $\mathrm{MPa}$ with little limitation for crops; medium 2.6-5.0 $\mathrm{MPa}$ with some limitations for crops; 5.1-10.0 MPa high with severe limitations for crops; 10.1 to $15.0 \mathrm{MPa}$ very high where the roots do not grow virtually; $>15.0 \mathrm{MPa}$ extremely high the roots do not grow. In general, the study area is not a problem for root growth, since rarely exceeds the value of $5 \mathrm{MPa} P R$ $\left(\mathrm{PR}_{0.4-0.5}, \mathrm{PR}_{0.5-0.6}\right.$, and $\mathrm{PR}_{0.6-0.7}$ ) (Table 1 ) indicating that the study area has medium $\mathrm{PR}$ with few limitations for cultivation and some areas with low PR, according to the classification of Canarache [6].

Table 5 shows the fitted parameters of cross variogram models between $\log \mathrm{PR}_{\text {average } 0.0-0.4} \times \log \mathrm{EC}_{\mathrm{a}}-\mathrm{V}, \mathrm{Log}$
$\mathrm{PR}_{\text {average 0.0-0.4 }} \times \log \mathrm{EC}_{\mathrm{a}}-\mathrm{H}, \log \mathrm{PR}_{\text {average 0.4-0.9 }} \times \log \mathrm{EC}_{\mathrm{a}}-$ $\mathrm{V}$, and $\log \mathrm{PR}_{\text {average } 0.4-0.9} \times \log \mathrm{EC}_{\mathrm{a}}-\mathrm{H}$, since these were the only attributes that showed an improvement in the coefficient of correlation between the measured and estimated values obtained using kriging and cokriging (Table 5).

PR maps made by universal cokriging (Figure 7) are less smooth when compared with PR maps made by ordinary kriging (Figure 6), although the improvement obtained with the use of the estimate cokriging PR has been small.

\section{Conclusions}

The data sets $\mathrm{EC}_{\mathrm{veris}}$ and PR showed low values of coefficient of variation $(\mathrm{CV}, \%)$, except for $\mathrm{PR}$ at 0.0-0.1 m layer that has a high value of CV (60.30\%). The spherical model was fitted to the data of soil resistance penetration $\left(\mathrm{PR}_{0.0-0.1}\right.$, $\mathrm{PR}_{0.1-0.2}, \mathrm{PR}_{0.2-0.3}, \mathrm{PR}_{0.3-0.4}$, and $\mathrm{PR}_{0.4-0.5}$ ) at the top soil layers. The presence of pure nugget effect for soil penetration resistance at the bottom $\left(\mathrm{PR}_{0.5-0.6}, \mathrm{PR}_{0.6-0.7}, \mathrm{PR}_{0.7-0.8}\right.$, and $\left.\mathrm{PR}_{0.8-0.9}\right)$ may be caused by the limited number of data available for these layers, since the recorded PR values were 
often not useful, as they were higher than the maximum value measured by the penetrometer $(5.5 \mathrm{MPa})$. Apparent soil electrical conductivity data $\left(\mathrm{EC}_{\mathrm{a}}\right)$ were used to determine the optimized sampling scheme where PR was measured, and this methodology has proved to be efficient and capable for representing the spatial pattern of $\mathrm{PR}$. $\mathrm{EC}_{\mathrm{a}}$ and $\mathrm{PR}$ data show significant negative correlation coefficients, once both properties are related to the soil water content. The use of $\mathrm{EC}_{\mathrm{a}}$ as secondary variable improved slightly the estimation of $\mathrm{PR}$ using universal cokriging with respect to kriging.

\section{Acronyms}

$\mathrm{EC}_{\mathrm{a}}$ : Apparent soil electrical conductivity

$\mathrm{EC}_{\mathrm{veris}}$ : Soil electrical conductivity measured with penetrometer Veris P3000

PR: $\quad$ Soil resistance to penetration

$\mathrm{EC}_{\mathrm{a}}-\mathrm{H}$ : Apparent soil electrical conductivity in horizontal dipole

$\mathrm{EC}_{\mathrm{a}}-\mathrm{V}$ : Apparent soil electrical conductivity in vertical dipole

CV: Coefficient of variation.

\section{Conflict of Interests}

The authors declare that there is no conflict of interests regarding the publication of this paper. The referencing brands of commercial products in the paper do not imply that the authors recommend the equipment utilized this study. The support funds presented by the Development Agencies do not show conflict of interests regarding the publication of this paper.

\section{Acknowledgments}

The authors are grateful to the Ministerio de Asuntos Exteriores y de Cooperación (MAEC-AECID) from Spain for the granting of scholarships for Ph.D. studies. This work has been funded by Ministerio de Educación y Ciencia, within the framework of research Projects CGL200508219-C02-02 and CGL2009-13700-C02-02, co-funded by Xunta de Galicia, within the framework of research project PGIDIT06PXIC291062PN and by the European Regional Development Fund (ERDF). The authors would like to thank FACEPE and CNPq (Brazil) for the scholarship DCR granted to the first author. Thanks are due to FAPEMA financial support for publication.

\section{References}

[1] A. W. Warrick and D. R. Nielsen, "Spatial variability of soil physical properties in the field," in Applications of Soil Physics, D. Hillel, Ed., pp. 319-344, Academic Press, New York, NY, USA, 1980.

[2] A. Utset and G. Cid, "Soil penetrometer resistance spatial variability in a Ferralsol at several soil moisture conditions," Soil \& Tillage Research, vol. 61, no. 3-4, pp. 193-202, 2001.

[3] C. J. Gerard, H. C. Mehth, and F. Hinojosa, "Root growth in a clay soil," Soil Science, vol. 114, pp. 37-49, 1972.
[4] H. H. Becher, "Resistances to penetration of aggregates from loess-derived topsoils at different soil water tensions," Soil \& Tillage Research, vol. 47, no. 1-2, pp. 73-81, 1998.

[5] A. G. Benghough, D. J. Campbell, and M. F. O'Sullivan, "Penetrometer techniques in relation to soil compaction and root growth," in Soil and Environmental Analysis: Physical Methods, K. A. Smith and C. E. Mullins, Eds., pp. 377-404, Marcel Decker, New York, NY, USA, 2001.

[6] A. P. Canarache, "PENETR—a generalized semi-empirical model estimating soil resistance to penetration," Soil \& Tillage Research, vol. 16, no. 1-2, pp. 51-70, 1990.

[7] A. Merotto and C. M. Mundstock, "Wheat root growth as affected by soil strength," Revista Brasileira de Ciencias do Solo, vol. 23, pp. 197-202, 1999.

[8] M. A. Arshad, B. Lowery, and B. Grossman, "Physical tests for monitoring soil quality," in Methods for Assessing Soil Quality, SSSA Special Publication, J. W. Doran and A. J. Jones, Eds., vol. 49, pp. 123-141, Soil Science Society of America, Madison, Wis, USA, 1996.

[9] R. L. Hill and M. Meza-Montalvo, "Long-term wheel traffic effects on soil physical properties under different tillage systems," Soil Science Society of America Journal, vol. 54, no. 3, pp. 865-870, 1990.

[10] A. B. McBratney and M. J. Pringle, "Spatial variability in soil, implications for precision agriculture," in Spatial Variability in Soil and Crop, J. V. Satafford, Ed., vol. 1 of Precision Agriculture '97, pp. 3-31, Bios Scientific Publishers, Warwick, UK, 1997.

[11] J. D. Rhoades, P. C. A. Raats, and R. J. Prather, "Effects of liquid-phase electrical conductivity, water content, and surface conductivity on bulk soil electrical conductivity," Soil Science Society of American Journal, vol. 40, no. 5, pp. 651-655, 1976.

[12] A. Nadler, "Estimating the soil water dependence of the electrical conductivity soil solution/electrical conductivity bulk soil ratio.," Soil Science Society of America Journal, vol. 46, no. 4, pp. 722-726, 1982.

[13] J. D. McNeill, "Electrical conductivity of soils and rocks," Tech. Rep. TN-5, Geonics Ltda, Ontario, Canada, 1990.

[14] N. R. Kitchen, K. A. Sudduth, and S. T. Drummond, "Mapping of sand deposition from 1993 midwest floods with electromagnetic induction measurements," Journal of Soil and Water Conservation, vol. 51, no. 4, pp. 336-340, 1996.

[15] E. C. Brevik and T. E. Fenton, "Soil sensing techniques as soil survey tools in lacustre-derived soils, central Iowa (CD)," in International Econference on Precision Agriculture, vol. 5, ASACSSA-SSSA, Bloomington, Ind, USA, 2000.

[16] N. J. Harstock, T. G. Mueller, G. W. Thomas, R. I. Barnhisel, and K. L. Wells, "Soil electrical conductivity variability $(\mathrm{Cd})$," in Proceedings of the 5th International Conference on Precision Agriculture and Other Resource Management, Bloomington, MN. 16-19 July 2000, ASA-CSSA-SSSA, Madison, Wis, USA, 2000.

[17] R. G. Kachanoski, E. de Jong, and I. J. van Wesenbeeck, "Field scale patterns of soil water storage from non-contacting measurements of bulk electrical conductivity," Canadian Journal of Soil Science, vol. 70, no. 3, pp. 537-541, 1990.

[18] P. G. Cook and G. R. Walker, "Depth profiles of electrical conductivity from linear combinations of electromagnetic induction measurements," Soil Science Society of America Journal, vol. 56, no. 4, pp. 1015-1022, 1992.

[19] K. R. Sheets and J. M. H. Hendrickx, "Noninvasive soil water content measurement using electromagnetic induction," Water Resources Research, vol. 31, no. 10, pp. 2401-2409, 1995. 
[20] J. D. Rhoades, "Electrical conductivity methods for measuring and mapping soil salinity," Advances in Agronomy, vol. 49, pp. 201-251, 1993.

[21] FAO-ISRIC, World Reference Base for Soil Resources, FAO, Rome, Italy; ISRIC, Wageningen, The Netherlands, 1994.

[22] G. M. Siqueira, J. Dafonte, M. Valcárcel-Armesto, and F. F. de França e Silva, "Using multivariate geostatistics to assess patterns of spatial dependence of apparent soil electrical conductivity and selected soil properties," The Scientific World Journal, 2014.

[23] S. M. Lesch, J. D. Rhoades, and D. L. Corwin, The ESAP Version 2.01r User Manual and Tutorial Guide, Research Report vol. 146, George E. Brown Jr., Salinity Laboratory, Riverside, Calif, USA, 2000, http://www.ussl.ars.usda.gov/lcrsan/esap95.pdf.

[24] P. E. Drummond, C. D. Christy, and E. D. Lund, "Using an automatic penetrometer and soil $\mathrm{EC}_{a}$ probe to characterize the rooting zone," in Proceedings of the 5th International Conference on Precision Agriculture, ASA-CSSA-SSSA, Bloominghton, Minn, USA, July 2000.

[25] F. E. Harrell Jr., Hmisc: Harrell Miscellaneous R Package version 3.14-5, 2014, http://cran.r-project.org/web/packages/Hmisc/ index.html.

[26] E. J. Pebesma and B. Graeler, Package Gstat, 2013, http://cran.rproject.org/web/packages/gstat/gstat.pdf.

[27] P. Goovaerts, Geostatistics for Natural Resources Evaluation, Oxford University Press, New York, NY, USA, 1997.

[28] P. Goovaerts, "Geostatistics in soil science: State-of-the-art and perspectives," Geoderma, vol. 89, no. 1-2, pp. 1-45, 1999.

[29] C. V. Deutsch and A. G. Journel, GSLIB-Geostatistical Software Library and User's Guide, Oxford University Press, New York, NY, USA, 2nd edition, 1998.

[30] C. K. Johnson, J. W. Doran, H. R. Duke, B. J. Wienhold, K. M. Eskridge, and J. F. Shanahan, "Field-scale electrical conductivity mapping for delineating soil condition," Soil Science Society of America Journal, vol. 65, no. 6, pp. 1829-1837, 2001.

[31] P. P. Motavalli, S. H. Anderson, P. Pengthamkeerati, and C. J. Gantzer, "Use of soil cone penetrometers to detect the effects of compaction and organic amendments in claypan soils," Soil \& Tillage Research, vol. 74, no. 2, pp. 103-114, 2003.

[32] K. A. Sudduth, J. W. Hummel, N. R. Kitchen, and S. T. Drummond, "Evaluation of a soil conductivity sensing penetrometer," in Proceedings of the American Society of Agricultural Engineers Annual International Meeting, Paper No. 001043, American Society of Agricultural Engineers, St. Joseph, Mich, USA, July 2000.

[33] K. A. Sudduth, J. W. Hummel, and S. T. Drummond, "Comparison of the veris profiler 3000 to an ASAE-standard penetrometer," Applied Engineering in Agriculture, vol. 20, no. 5, pp. 535541, 2004.

[34] X. X. Neira, Development of Water Management Methods for Rational Water Use in Irrigation, Universidade de Santiago de Compostela, Escola Politécnica Superior, 1993, (Spanish).

[35] D. S. Nesmith, D. E. Radcliffe, W. L. Hargrove, R. L. Clark, and E. W. Tollner, "Soil compaction in double-cropped wheat and soybeans on an Ultissol," Soil Science Society of America Journal, vol. 51, no. 1, pp. 183-186, 1987.

[36] M. Yasin, R. D. Grisso, L. L. Bashford, A. J. Jones, and L. N. Mielke, "Normalizing cone resistance values by covariance analysis," Transactions of the American Society of Agricultural Engineers, vol. 36, no. 5, pp. 1267-1270, 1993.
[37] H. M. Taylor and H. R. Gardner, "Penetration of cotton seedling taproots as influenced by bulk density and, moisture content, and strength of soil," Soil Science, vol. 96, no. 3, pp. 153-156, 1963.

[38] H. M. Taylor and E. Burnett, "Influence of soil strength on the root-growth habits of plants," Soil Science, vol. 98, pp. 174-180, 1964.

[39] W. Ehlers, U. Köpke, F. Hesse, and W. Böhm, "Penetration resistance and root growth of oats in tilled and untilled loess soil," Soil and Tillage Research, vol. 3, no. 3, pp. 261-275, 1983.

[40] J. Letey, "Relationship between soil physical properties and crop production," Advances in Soil Science, vol. 1, pp. 277-294, 1985.

[41] J. Bueno, C. Amiama, J. L. H. Hernanz, and J. M. Pereira, "Penetration resistance, soil water content, and workability of grasslands soils under two tillage systems," Transactions of the American Society of Agricultural and Biological Engineers, vol. 49, no. 4, pp. 875-882, 2006.

[42] A. T. P. Bennie, "Growth and mechanical impedance," in Plant Roots the Hidden Half, pp. 393-414, Marcel Dekker, New York, NY, USA, 1991.

[43] J. Bueno, Forrage maize under no-tillage in wet conditions, comparison with traditional tillage in soil response, yield and energy budget [Ph.D. thesis], Universidad Politécnica de Madrid, 1997 (Spanish).

[44] C. Amiama, Italian Raygrass under no-tillage, influence of residues from last crop and comparison with traditional tillage of physical soil properties, yield and economic aspects [Ph.D. dissertation], Universidad de Santiago de Compostela, 2003, (Spanish).

[45] G. Hoefer, J. Bachmann, and K. H. Hartge, "Can the EM38 probe detect spatial patterns of subsoil compaction?" in Proximal Soil Sensing, R. A. V. Rossel, A. B. McBratney, and B. Minasny, Eds., vol. 1 of Progress in Soil Science, pp. 265-273, Springer Science, Dordrecht, The Netherlands, 2010.

[46] C. A. Cambardella, T. B. Moorman, J. M. Novak et al., "Field scale variability of soil properties in central Iowa soils," Soil Science Society of America Journal, vol. 58, no. 5, pp. 1501-1511, 1994.

[47] J. D. Jabro, R. G. Evans, Y. Kim, W. B. Stevens, and W. M. Iversen, "Characterization of spatial variability of soil electrical conductivity and cone index using coulter and penetrometer-type sensors," Soil Science, vol. 171, no. 8, pp. 627-637, 2006. 

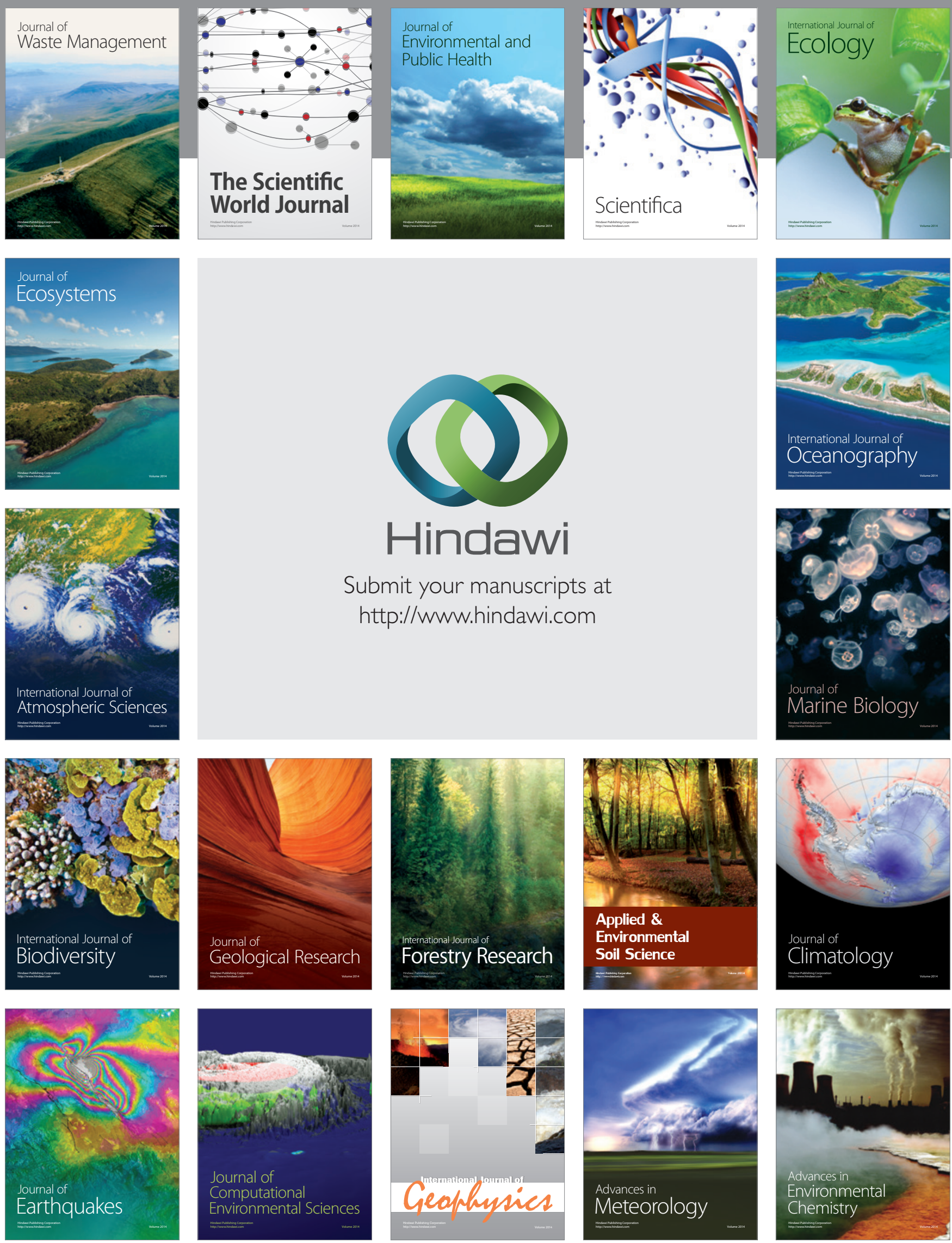